\title{
TB or not TB?
}

Cite as: CMAJ 2017 February 13;189:E247-8. doi: 10.1503/cmaj.160828

CMAJ Podcasts: article reading at https://soundcloud.com/cmajpodcasts/160828-enc

$\mathrm{T}$ here was too much of a gap between the markings of the occupational health nurse's pen on my arm; I knew it wasn't a great sign. She took out her ruler to go through the motions of measuring it more precisely - our glances betrayed the fact that we both knew the induration was well over $10 \mathrm{~mm}$ before she even put ruler to skin. She pursed her lips for a second, almost stumbling before letting the words escape into the ether, "Any night sweats? Hemoptysis? Weight loss? Fatigue?" My rapid-fire negative answers shot back tersely at her in the volley of a patient history. "While you don't have active TB, it looks like you've come in contact with someone with TB since your last test and have been infected."

Most people would have been worried; I chose instead to distance myself from my reality. I remembered the first time I had worked with Mycobacteria in my undergraduate microbiology laboratory course. I had squinted through the microscope to see innocuous-looking fuchsia rods staring back at me through a sea of methylene blue; arabinogalactans capped with mycolic acid enveloping the bacteria, making the Gram stain futile in our attempts to identify the samples we had been given.

Suppressing that first wave of anxiety seemed to help, but it appeared like my body already had other ideas: my right little finger started to twitch, as it often did before I walked into my clinical exams. I tried to will it away, make my muscles submit to me, but the twitches kept coming. My thoughts were interrupted by the nurse asking me if I had understood the information she had given me - I distractedly muttered in the affirmative.

Then, of course, came an immediate litany of paperwork. Public Health needed to know. The hospital needed to know. The postgraduate medical education office needed to know. My private health information, I was assured, would remain private - after they were done with it.

The thick air of the city hit me as soon as I headed back toward the hospital for my radiograph. I was suddenly hyperaware of my lungs. They felt much tighter, like I needed a puff from the long-forgotten inhaler I kept in a dank corner of my medi-

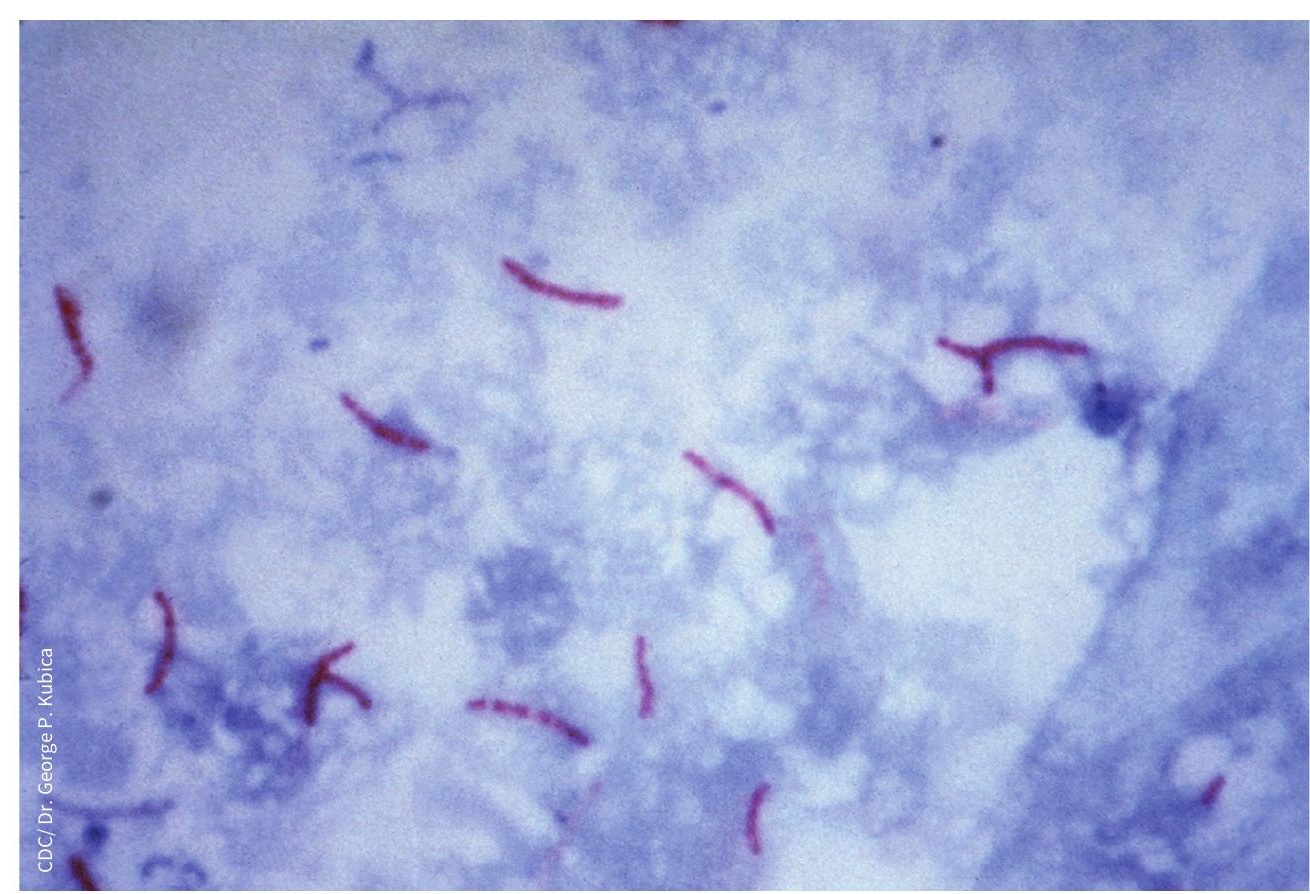

cine cabinet. I could barely keep pace with the thoughts that now flooded into my brain. Perhaps my body was becoming physically aware of the granulomas my immune system was presumably wellacquainted with; perhaps macrophages were fusing together, frustrated by the microbe's ability to thwart their defenses and escape destruction. Perhaps I harboured a multidrug-resistant strain that would stay with me for life and reactivate months after my retirement, as my worldweary body eventually gave itself up to those innocuous fuchsia rods. In the postantibiotic age, would I end up like my favourite author George Orwell, staining my pillows with blood every morning until an artery decided to burst in my lungs?

I began to focus on the tidal volumes of everyone I was passing on my way back to the pallid, towering hospital building: the homeless man with his wizened hair and 
The lobby, recently renovated with a glut of donor money, was fresh and clean, but filled with sick patients in stasis who were aimlessly wandering but going nowhere. I felt like I belonged with them. In the medical imaging waiting room, I reconsidered that thought: I was the lone pair of scrubs in the sea of civilian clothes. The tension of the other patients' eyes transfixing on my "otherness" among them was broken by the patient-care coordinator who beckoned me forward. He was a man of about 50, with salt-and-pepper hair tied back into a ponytail - someone who shed his day job every evening for a more gratifying encounter with a bass guitar.

"Where's your hospital card?" he demanded as I passed him the requisition form.

"Don't have one," I countered defiantly.

"You mean to tell me you've never once needed to come here?" The weight of his voice fell on the last word as if to stress the significance of how rare it was that I had never been sick enough to be admitted to hospital before.

"Well, at least l've got a good reason to show up now."

He chuckled as he glanced down at my requisition: "Hell of a reason."

My phone buzzed again as I walked to the imaging room, reminding me to answer the text. Instead, I made small talk with the radiology technician about where I worked in the hospital, wondering aloud if I could get back into the operating room to catch the next Caesarian delivery as I took off my scrubs and stood bare-chested against the cassette. A few clicks of the machine, and all that was left to do was wait - wait for my lucencies and densities to show up on the radiologist's computer; wait for her eyes to dissect the image as precisely as the anatomist carving into a cadaver's flesh; wait for the dictation to wind its way through the purgatory of medical transcription; wait for them to tell me I needed a sputum culture to confirm the worst; wait for my prescription of isoniazid to keep me occupied for the next nine months; wait to hear tomorrow that my life had been altered for the foreseeable future.

As I walked home from work that evening, my phone buzzed yet again. My hand hesitated as I reached into my scrub pocket, then stopped a moment before plunging in. A simple "?" from Mom. One character. A punctuation mark. Its weight hung over me the entire night. Suddenly, the pollutant-laden air filling my lungs seemed light in comparison.

I had the first appointment with the nurse the next morning. I exhaled deeply before I crossed through the examination room door. Sighing on a regular basis was another peculiarity of mine, but this one was different. It was as if I had wanted to experience what breathing was like for the last time before I knew for sure that my lungs were pathological. Torschlusspanik, it is said in German. Literally, gate-close panic: the fear that the window of opportunity to act was closing.

The door closed.

The nurse barely took a breath after her perfunctory greeting, launching immediately into reporting my results: "Adam, your chest radiographs are clear. We'll book a follow-up with respirology in a week." There was an uneasy lightness about my lungs, as though my body was remembering what it was like to forget they were there. Released from the bonds of illness - my muscles still twitching, my mind still racing. The simple process of a screening test had made me feel thrashed about by the system that was training me to operate within its confines. I wanted to find the words to express my bewilderment and anger at the process, but my lips could only form a simple "thanks." Before I could register it, I was out of the examination room.

I finally answered my mother's text as I left the building, the door wide open in front of me: "Not sure how it went. But I'm negative."

\section{Adam S. Komorowski Hon BSc}

Second-year medical student University of Limerick, Castletroy, Limerick, Ireland

This article has been peer reviewed.

This is a true story. 